Original scientific paper - Izvorni znanstveni rad

UDK: 637.045

\title{
Polymorphism of $\kappa$-casein and $\beta$-lactoglobulin genes in Busha and Holstein Friesian dairy cows in Serbia
}

doi: $10.15567 /$ mljekarstvo.2016.0304

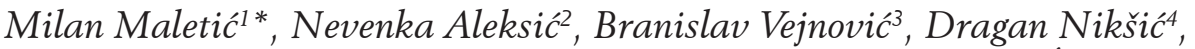 \\ Milan Kulić5, Božidar Đukić, Dragan Ćirković ${ }^{7}$
}

${ }^{1}$ Department of Reproduction, Fertility and Artificial Insemination, Faculty of Veterinary Medicine, University of Belgrade, Bul. oslobođenja 18, 11000 Belgrade, Serbia ${ }^{2}$ Department of Parasitology, Faculty of Veterinary Medicine, University of Belgrade, Bul. oslobođenja 18, 11000 Belgrade, Serbia ${ }^{3}$ Department of Biology, Faculty of Veterinary Medicine, University of Belgrade, Bul. oslobođenja 18, 11000 Belgrade, Serbia

${ }^{4}$ Institute for Animal Husbandry, Autoput 16, 11080 Belgrade-Zemun, Serbia ${ }^{5}$ Department for human genetics, Faculty of Medicine, University of East Sarajevo, Studentska 5, 73300 Foča, Republic of Srpska, Bosnia and Herzegovina ${ }^{6}$ Medicines and Medical Devices Agency of Serbia, Vojvode Stepe 451, 11221 Belgrade ${ }^{7}$ Department of Chemical and Technological Sciences, State University of Novi Pazar, Vuka Karadžića bb, 36300 Novi Pazar, Serbia

Received - Prispjelo: 11.01.2016. Accepted - Prihvaćeno: 16.05.2016.

\begin{abstract}
The aim of this study was to determine the distribution of $\kappa$-casein $(\kappa-\mathrm{CN})$ and $\beta$-lactoglobulin $(\beta-\mathrm{Lg})$ genotypes in the autochtonous (Busha) and dairy (Holstein-Friesian, HF) cattle breeds with PCR-RFLP (polymerase chain reaction - restriction fragment length polymorphism). For the amplification of $\kappa-\mathrm{CN}$ and $\beta-\mathrm{Lg}$ gene fragments specific primers were used. After digestion with specific endonucleases genotypes were determined for both genes in 18 Busha and 19 HF cows. The results showed that $\kappa-\mathrm{CN}$ gene was represented with the AA genotype in $31.58 \% \mathrm{HF}$ cows, AB in $52.63 \%$ cows, whilst the genotype BB was found in $15.79 \%$ cows only. Among the examined Busha cattle $44.44 \%$ cows had AA genotype and $55.56 \%$ genotype $\mathrm{AB}$ for $\kappa-\mathrm{CN}$. As for $\beta$-Lg gene in HF breed, AA genotype was found in $26.31 \%$ cows, $\mathrm{AB}$ in $63.16 \%$ and $\mathrm{BB}$ in $10.53 \%$ cows. In Busha cows the following genotypes were established for $\beta$ - $\mathrm{Lg}$ gene: $\mathrm{AA}$ in $44.44 \%$ cows and $\mathrm{AB}$ in $55.56 \%$, whilst $\mathrm{BB}$ genotype was not found. These results indicate that Busha cows had a higher presence of A allelic forms of both genes ( $\mathrm{k}-\mathrm{CN}$ and $\beta$-lactoglobulin) than HF cows.
\end{abstract}

Key words: $\kappa$-casein, $\beta$-lactoglobulin, polymorphism, PCR-RFLP, Holstein-Friesian, Busha cattle

\section{Introduction}

Milk proteins are a large group of organic compounds important for the structure and proper function of the mammal organism. Side-chains of standard aminoacids have various chemical properties, which result in three-dimensional protein structures with various activities (Sharma et al., 2013). The polymorphism of milk proteins was noticed more than half a century ago, which prompted the research on its influence on lactation and processing properties of milk. The development of polymerase chain reaction (PCR) technique enabled the identification of the polymorphism of milk proteins immediately on the coding sequence of the corresponding

*Corresponding author/Dopisni autor: E-mail: maletic@vet.bg.ac.rs 
gene, regardless of the age, sex or milk secretion od cows (Stanimirović and Stevanović 2012; Stanimirović et al., 2015). The determination of the genetic profile of autochthonous and commercial populations of cattle is necessary for the protection of endangered autochthonous breeds and improvement of animal production, respectively (Caroli et al., 2009; Stevanović et al., 2010). The analysis of the polymorphism of proteins, $\beta$-lactotglobulin $(\beta-\mathrm{Lg})$ and kappa casein $(\kappa-\mathrm{CN})$, is part of modern animal production which may functionally improve the cattle populations (Ivanković et al., 2011).

Casein is the most abundant protein of the cow's milk and contributes $80 \%$ of total proteins, whilst the rest is composed of the proteins of whey or milk serum (Patel et al., 2007). Casein is the main component of cheese. In the process of cheese production, it is precipitated under the influence of an enzyme - rennin, and the coagulum, or curd, which is formed contains casein, whey proteins, fat, lactose and minerals from milk. Kappa casein $(\kappa-\mathrm{CN})$ is one of the four protein fractions of casein and is determined by the gene which is positioned on the chromosome 6 in cattle (Caroli et al., 2009). $\beta$-lactoglobulin is one of the prevalent whey proteins which is discovered in animal milk, including sheep's, cow's, swine and dog's milk, but has not been found in the mouse and other mammals. Due to intra- and interspecific genetic variations it exists in several variants. In the last decades the determination of genetic polymorphism of milk proteins is targeted by researchers because of possible link between the genotypes and economically important traits of dairy cattle (Dokso et al., 2014; Lukač et al., 2015). Numerous authors proved the link between polymorphic allelic variants of $\beta$-Lg and $\kappa-\mathrm{CN}$, and lactation characteristics and milk properties important for processing. Thus, in marker-assisted selection (MAS) the frequently assessed genetic markers are $\kappa$-casein and $\beta$-lactoglobulin. The assessment of the polymorphism of genes which code $\kappa$-casein is important because of the influence of this protein on the quality and composition of ruminants' milk. $\kappa$-casein contributes about $12 \%$ of total casein (Azevedo et al., 2008). Genetic variability of $\kappa$-casein genes has been assessed in several cattle breeds; numerous investigations suggest that there are differences between cows with various geno- types concerning lactation and the characteristics of milk which are important for milk processing and cheese production (Hallen et al., 2008; Alipanah et al., 2005). Kappa casein is one of the four protein fractions of casein. Caroli et al. (2009) claim that there are forteen polymorphic variants out of which $A$ and $B$ are most frequent. $\beta$-lactoglobulin is a stabile whey protein built of a single-chained polypeptide made of 162 amino acids. The complete amino acid sequence was determined (Creamer et al., 1983). The biological function of this protein has yet to be defined precisely, but is considered to play role in the metabolism of phosphates in the udder and the transport of retinol and fatty acids in the intestines (Hill, 1997). The gene coding $\beta$-lactoglobulin is on chromosome 11. Its polymorphism was discovered in 1935 (Aschaffenburg and Drewry), when two allelic forms were established: A and B. This has been followed by avid interest in the assessment of these polymorphisms because certain differences were noticed in the composition and the quality of milk in cows of different genotypes for this protein.

The development of PCR-RFLP (Polimerase Chain Reaction - Restriction Fragment Lenght Polymorphism) technique enabled fast analysis of the polymorphisms of virtually unlimited number of genes, including those coding $\kappa$-casein and $\beta$-lactoglobulin. The aim of this research was to assess the polymorphism of the genes for casein and $\beta$-lactoglobulin as well as the distribution of the genotypes in the populations of autochthonous (Busha) and high-producing (Holstein-Frisian) cow breeds.

\section{Material and methods}

The research was conducted on two groups of animals, each comprising 20 cows of Busha and Holstein-Friesian breed, respectively. From each cow $10 \mathrm{~mL}$ of blood was sampled from the caudal vein (vena coccigea media) and placed in test tubes containing potassium ethylenediaminetetraacetic acid $\left(\mathrm{K}_{2}\right.$-EDTA). All the test tubes were marked with a permanent marker and the blood samples transported into the laboratory in a refrigerator.

DNA was extracted from the cows' blood following the protocol provided by the producer of the chemicals, Kapa-Biosystems: $1.5 \mathrm{~mL}$ Eppendorf ${ }^{\circledR}$ 
microcentrifuge tubes were filled with $15 \mu \mathrm{L}$ of $10 \mathrm{x}$ KAPA Express Extract Buffer and $285 \mu \mathrm{L}$ of water. From each test tube containing blood a sample was taken with a sterile cotton swab and transferred into $300 \mu \mathrm{L}$ of prepared buffer solution prior to sealing the microcentrifuge tubes and homogenisation of the contents with vorteks mixer. Finally, the test tubes were kept for 20 minutes at $75^{\circ} \mathrm{C}$, plus for 5 minutes at $95{ }^{\circ} \mathrm{C}$. The digestion was followed by mixing with vortex mixer. To separate the supernatant, which contained the extracted DNK, the samples were centrifuged for 1 minute at $1300 \mathrm{rpm}$. With automatic pipettes $50-\mu \mathrm{L}$ aliquots were transferred into new Eppendorf tubes containing $2 \%$ solution of stabilising TE buffer. The processed DNK was stored at $-20{ }^{\circ} \mathrm{C}$.

For the amplification of the analysed fragment of the $\mathrm{K}$-casein gene the following 379-bp-long primer was used: 5'-CAC GTC ACC CAC ACC CAC ATT TATC-3', 5'-TAA TTA GCC CAT TTC GCC TTC TCT GT -3' (Mitra et al., 1998). The corresponding 252-bp-long primer pair for $\beta$-lactoglobulin was 5'GTC CTT GTG CTG GAC ACC GAC TAC A -3' and5'-CAG GAC ACC GGC TCC CGG TAT ATG A -3' (Medrano and Aguilar-Cordova, 1990). The PCR mixture was prepared in microcentrifuge tubes and consisted of $12.5 \mu \mathrm{L}$ KAPA 2G Robust HotStart ReadyMix (Kapa Biosystems), $1.25 \mu \mathrm{L}$ of each primer and $10 \mu \mathrm{L}$ of isolated DNA. The samples were processed in Multi-Gene Gradient (Labnet International Inc.) processor. The thermal protocol for the first primer pair consisted of initial denaturation at $95{ }^{\circ} \mathrm{C}$ for 1 minute, followed by 30 cycles of annealing: denaturaton at $95^{\circ} \mathrm{C}$ for 30 seconds and primer hybridisation at $57^{\circ} \mathrm{C}$ for 30 seconds; the extension occurred at $72{ }^{\circ} \mathrm{C}$ and lasted 30 seconds. The final elongation took place at $72{ }^{\circ} \mathrm{C}$ during the last 8 minutes for both primer pairs. The thermal protocol for the second pair of primers differed only in that that the initial denaturation lasted 2 minutes and the hybridisation temperature was somewhat higher $\left(61^{\circ} \mathrm{C}\right)$.

The identification of $\mathrm{K}$-casein and $\beta$-lactoglobulin genotypes was completed using RFLP method following digestion of PCR products with the restriction enzymes: Hinf I for casein and Hae III for lactoglobulin. RFLP analysis detects alleles which differ in the presence or absence of restriction sites for enzymes (Botstein et al., 1980).
The PCR products were digested according to the recommandations of the producer of the restriction enzymes Hinf I and Hae III (New England Biolabs). The reaction mixture consisted of $12 \mu \mathrm{L}$ of deionized water, $2.5 \mu \mathrm{L}$ buffer fast enzyme, $0.5 \mu \mathrm{L}$ of restriction enzyme Hinf I $(5 \mathrm{U} / \mu \mathrm{L})$ or Hae III $(5 \mathrm{U} / \mu \mathrm{L})$, respectively, and $10 \mu \mathrm{L}$ of PCR products. The reaction took place at $37^{\circ} \mathrm{C}$ and lasted 90 minutes.

The digested fragments were processed in $2 \%$ agarose gel (Sigma-Aldrich) electrophoresis in TBE buffer for 60 minutes. The fragments were visualised with ethidium bromide and UV light. The length of the fragments was analysed with commercial 50-bp and 100-bp ladders (O'RangeRuler, Thermo Scientific).

The data obtained in this research were processed with statistical software Statistica 7 (StatSoft Inc., Tulsa, USA).

\section{Results}

The research was conducted on 18 Busha and 19 Holstein-Friesian (HF) cows. All of them were of similar age, in their second or third lactation. HF cows originated from a dairy farm in the vicinity of Belgrade, which contains about 280 animals kept in a free stall system, with the average milk production of 8,000 liters per lactation and fed on standard feed. By contrast, Busha cows were from a semi-wild herd dwelling on Stara planina mountain.

With the aim of detecting genotypes for $\kappa$-casein specific primers were used. The digestion of fragments was performed with specific endonuclease, when three genotypes were discovered $A A$, $\mathrm{AB}$ and $\mathrm{BB}$ in HF cows and only two, $\mathrm{AA}$ and $\mathrm{AB}$ in Busha. The fragment length of AA genotype measured 156, 132 and 91 bp, of $A B$ 288, 156, 132 and $91 \mathrm{bp}$, whilst for BB genotype the fragment consisted of 288 and 91 base pairs.

Blood samples from one HF and two Busha cows could not be amplified, despite of all efforts.

Results of the analysis of $\kappa-\mathrm{CN}$ gene showed that in HF cows 6 (31.58 \%) had AA genotype, 10 $(52.63 \%) \mathrm{AB}$ genotype and 3 cows $(15.79 \%)$ had BB genotype (Table 1, Figure 1). In the group of Busha cows 8 (44.44\%) had AA genotype and 10 (55.56 \%) AB genotype for $\kappa-\mathrm{CN}$ (Table 1, Figure 2). 
Calculated from the Hardy-Weinberg equation of the distribution of $\mathrm{AA}, \mathrm{AB}$ and $\mathrm{BB}$ genotypes for $\kappa$-casein in HF cows the proportion of allele frequencies is $\mathrm{A}: \mathrm{B}=57.89 \%: 42.11 \%$; the $\mathrm{Chi}^{2}$ $\mathrm{P}$-value $\mathrm{P}=0.728$ and thus, the population is at Hardy-Weinberg equilibrium. Similar conclusion may be drawn for the population of Busha cows which was assessed: the ratio of $\mathrm{A}$ to $\mathrm{B}$ alleles is $72.22 \%$ to $27.78 \%$, the $\mathrm{Chi}^{2} \mathrm{p}$-value $\mathrm{p}=0.1027$ and there is no reason to reject the null hypothesis that the population is in Hardy-Weinberg equilibrium. However, what is noticeable is the higher frequency of A allele and lower frequency of B in Busha in comparison to HF cows.
In the assessment of genotypes for $\beta$-lactoglobulin specific primers were deployed. On digestion with restrictive enzyme Hae III the PCR products gave rise to three genotypes, $\mathrm{AA}, \mathrm{AB}$ and $\mathrm{BB}$ in $\mathrm{HF}$ cows, and two genotypes, $\mathrm{AA}$ and $\mathrm{AB}$, in Busha. The length of the fragments for AA genotype was 144 and $108 \mathrm{bp}$, for $\mathrm{AB}$ 144, 180, 74 and $70 \mathrm{bp}$, whilst for the $\mathrm{BB}$ genotype the corresponding values were 108, 74 and 70 bp. In HF cows, AA genotype for $\beta$ - $\operatorname{Lg}$ gene was detected in 5 (26.32\%) cows, AB in $12(63.16 \%)$ and BB genotype in $2(10.53 \%)$ cows, (Table 2, Figure 3). In the population of Busha the genotypes for $\beta$-Lg gene were as follows:

Figure 1. Results of PCR-RFLP analysis of $\mathrm{K}$-casein gene in HF cows (2 \% agarose gel, restriction enzymeHinF I): Genotype AA - samples 2, 7 and 8; Genotype AB - samples 4, 5, 6 and 9; Genotype BB - samples 1 and 10; M 50-bp ladder

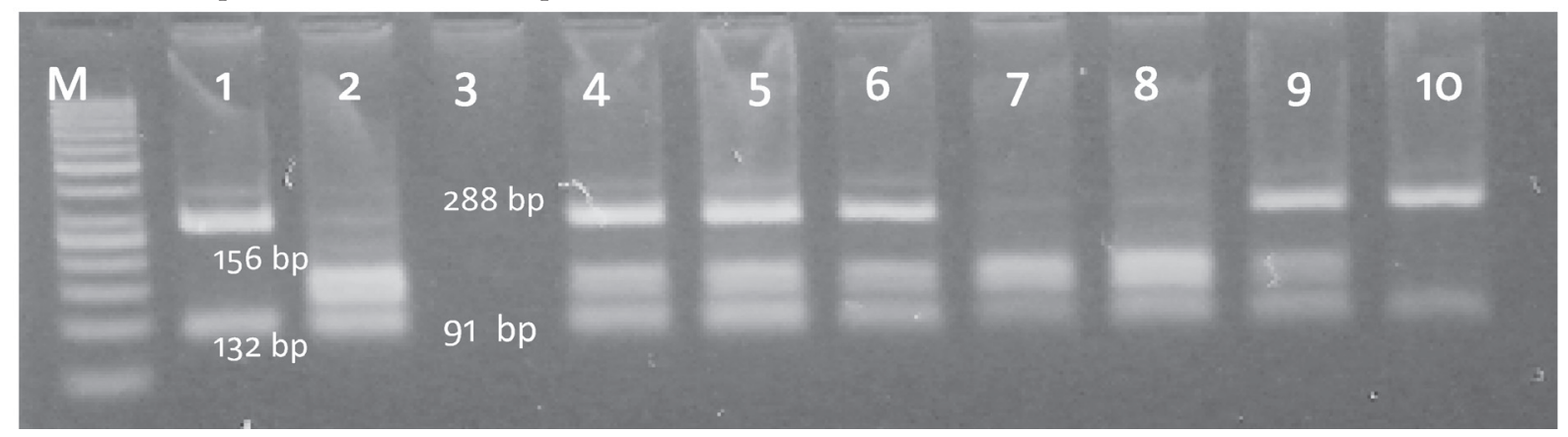

Figure 2. Results of PCR-RFLP analysis of $\mathrm{k}$-casein gene in Busha cows ( $2 \%$ agarose gel, restriction enzyme HinF I): Genotype AA - samples 1, 5, 8, 9, and 10; Genotype AB - samples 2, 3, 4, 6 and 7; M:50bp ladder

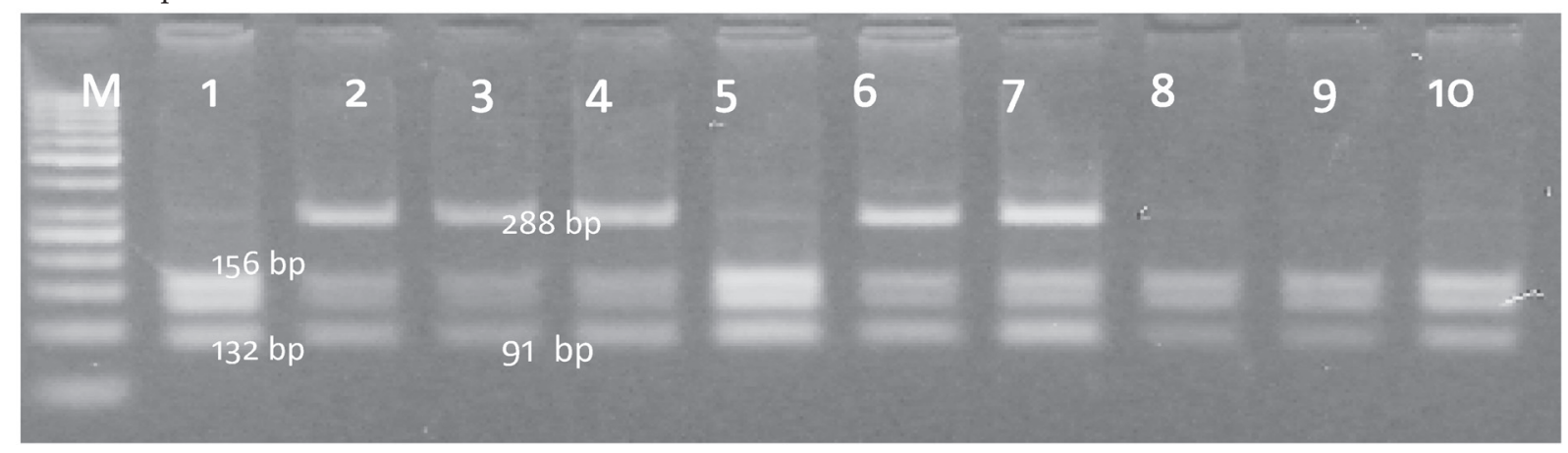

Table 1. Distribution of $\kappa$-kazein genotypes in cattle breeds

\begin{tabular}{cccccccccc}
\hline \multirow{2}{*}{ Breed } & \multicolumn{2}{c}{ Total } & \multicolumn{6}{c}{ Genotype } \\
\cline { 2 - 9 } & \multicolumn{2}{c}{ No. } & $\%$ & No. & $\%$ & No. & $\%$ & No. & $\%$ \\
\cline { 2 - 9 } & 19 & 100.00 & 6 & 31.58 & 10 & 52.63 & 3 & 15.79 \\
\hline Holstein-Friesian & 18 & 100.00 & 8 & 44.44 & 10 & 55.56 & 0 & 0.00 \\
\hline Busha & & & & & & & & & \\
\hline
\end{tabular}


$\mathrm{AA}$ in $8(44.44 \%)$ cows and $\mathrm{AB}$ in $10(55.56 \%)$ cows, whilst $\mathrm{BB}$ genotype was not detected at all (Table 2, Figure 4).

The frequencies of allele forms for $\beta$-lactoglobulin in the population of HF cows $A=57.89 \%$ and $B=42.11 \%$ do not differ significantly from the expected frequencies, which means that it is in Hardy-Weinberg equilibrium $(\mathrm{P}=0.1973)$. The same was true for the population of Busha cows, where the A allele was present in $72.22 \%$ and B in $27.78 \%$ animals and the $\mathrm{Chi}^{2} \mathrm{P}$ value was 0.1027 .
Not unlike alleles for $\kappa$-casein, the frequency of A allele for $\beta$-lactoglobulin was noticeably higher in Busha than in HF cows $(\mathrm{p}=0.1839)$.

\section{Discussion}

Early and precise identification of the polymorphism of milk proteins play an important role in the selection of dairy cattle (Scheepers et al., 2010). The application of PCR-RFLP technique for the detection of $\kappa$-casein and $\beta$-lactoglobulin gene

Figure 3. Results of PCR-RFLP analysis of $\beta$-lactoglobulin gene in HF cows $(2 \%$ agarose gel, restriction enzyme HaeIII): Genotype AA - samples 15 and 16; Genotype AB: samples 11, 12, 14, 18, 19 and 20; Genotype BB 17, M: 50-bp ladder

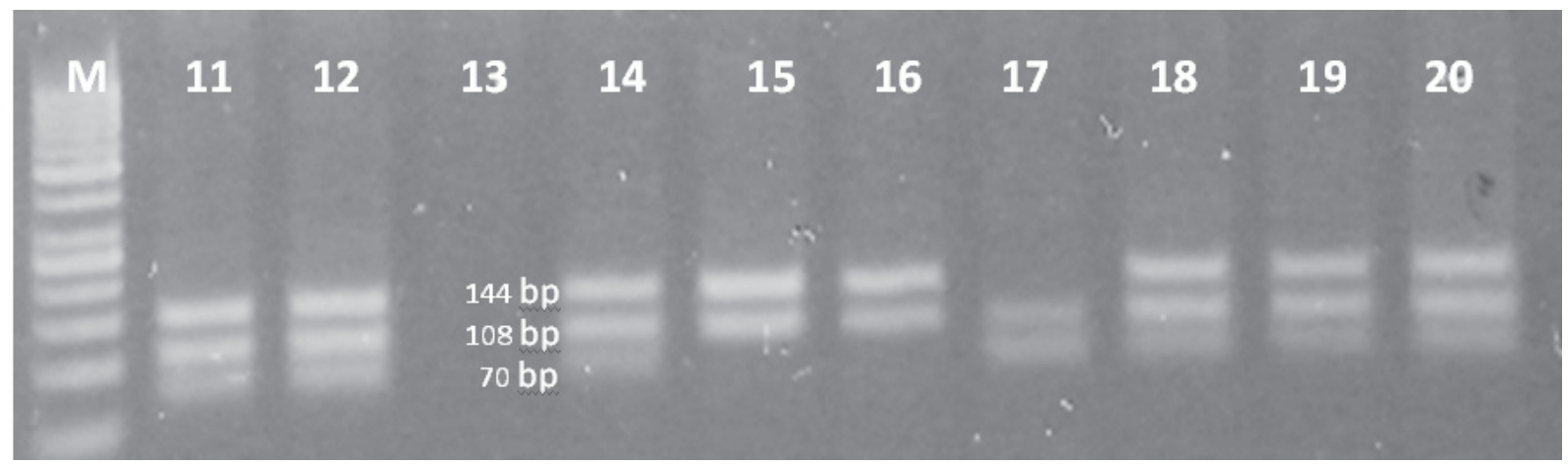

Figure 4. Results of PCR-RFLP analysis of $\beta$-lactoglobulin gene in Busha cows $(2 \%$ agarose gel, restriction enzyme HaeIII): Genotype AA - samples 11,16, 17, 19, and 21; Genotype AB: samples 12, 13, 14, 15 and 18; M: 50-bp ladder

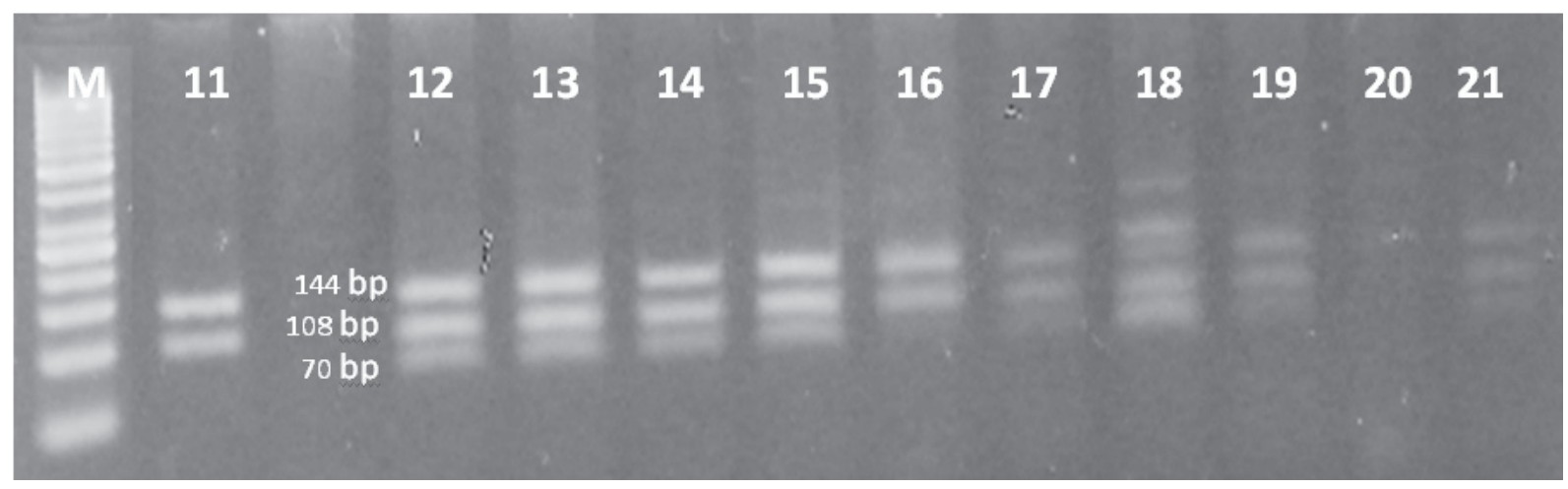

Table 2. Distribution of $\beta$-lactoglobulin genotypes in cattle breeds

\begin{tabular}{cccccccccc}
\hline \multirow{2}{*}{ Breed } & \multicolumn{2}{c}{ Total } & \multicolumn{7}{c}{ Genotype } \\
\cline { 2 - 9 } & \multicolumn{2}{c}{ Number } & $\%$ & No. & $\%$ & No. & $\%$ & No. & $\%$ \\
\cline { 2 - 9 } & 19 & 100.00 & 5 & 26.32 & 12 & 63.16 & 2 & 10.53 \\
\hline Holstein-Friesian & 18 & 100.00 & 8 & 44.44 & 10 & 55.56 & 0 & 0.00 \\
\hline Busha & & & & & & & & \\
\hline
\end{tabular}


polymorphisms permitted fast and efficacious determination of various genotypes in cows, regardless of their breed, age, milk production etc. Genetic variability for $\kappa$-casein has been detected in numerous cattle breeds, and the distribution of allelic frequencies is included into the research on the interspecies genetic varibility (Golijow et al., 1996; De lama and Zago, 1996).

In our research the existence of heterozygous $(\mathrm{AB})$ and both homozygous $(\mathrm{AA}$ and $\mathrm{BB})$ genotypes for $\kappa$-casein were detected in HF breed, whilst in Busha the heterozygous and only AA homozygous variants. The distribution of genotypes for $\kappa-\mathrm{CN}$ in our research resemble those published by Lukač et al. (2013), who among $420 \mathrm{HF}$ cows detected AA genotype in $25 \%, \mathrm{AB}$ in $52 \%$ and $\mathrm{BB}$ in $23 \%$. However, on another occasion (Lukač et al., 2015), in Vojvodina, quite different percentages were proven in $192 \mathrm{HF}$ cows: $50 \%$ with $\mathrm{AA}, 40 \%$ with $\mathrm{AB}$ and $10 \%$ with $\mathrm{BB}$ genotypes for $\kappa-\mathrm{CN}$. Rather similar results were provided by Dokso et al. (2014) for HF cattle in Croatia: the incidence of genotypes for $\kappa-\mathrm{CN}$ was AA $62.9 \%, \mathrm{AB} 27.1 \%$ and BB $10 \%$ (detected in 182 cattle), but differed slightly for Simmental cattle $(n=116, A A 41.6, A B 49.2$ and $B B$ 9.2) and the Brown cattle breed $(n=73$, $\mathrm{AA}$ 39.2, AB 44.9 and $\mathrm{BB}$ 15.9). Moreover, the ratio of $\kappa$-casein genotypes calculated in the current research was in accordance with the HW distribution in the population ( $\mathrm{p}>0.05)$, which corresponds to some previously published results ( $\mathrm{Ma}$ et al., 2007; Ju et al., 2008; Lukač et al., 2013).

The analysis of distribution revealed higher frequencies of $\mathrm{A}$ alleles for $\mathrm{\kappa}$-casein both in $\mathrm{HF}$ and in Busha cows (in HF A=57.89\%, B= $42.11 \%$; in Busha $\mathrm{A}=72.22 \%, \mathrm{~B}=27.78 \%$ ). These results are in accordance with the data observed by Azevedo et al., (2008) and Ivanković et al. (2011) concerning HF cows: Azevedo in HF and its crossbreds detected significantly higher frequencies of A alleles (77-79\%) than B. However, significantly higher frequency of A allele in Busha in Serbia stands in contrast with the findings of Ivanković et al. (2011), who assessed the genetic polymorhism of $\beta$-lactoglobulin and $\kappa$-casein in HF, Busha, Simmental, Braunvieh, Istrian and Podolian cattle in Croatia and found significantly higher frequencies of BB genotype (50 \%) and $\mathrm{B}$ allelic form $(64.7 \%)$ in comparison to our results. By contrast, the incidence of A allele in HF was found to be much higher according to previously published results - 70 \% (Lukač et al., 2015).

Higher frequencies of $\mathrm{A}$ allele for $\kappa$-casein in the current survey were found in both $\mathrm{HF}$ and $\mathrm{Bu}$ sha. It is supposed that the high incidence of $\mathrm{AA}$ homozygocity in this research is the consequence of very low numbers of Busha cattle (several locations in Serbia, with few dozen of animals: Zasavica, Krčedinska ada, Kovin, Stara Planina), which results in higher degrees of inbreeding in the population.

The genotyping of $\beta$ lactoglobulin $(\beta-\mathrm{Lg})$ gene in the present work revealed the dominance of A alelle in both cattle breeds. In HF cows AA genotype was detected in $26.32 \%, \mathrm{AB}$ in $63.16 \%$ and $\mathrm{BB}$ genotype in $10.53 \%$ cows only. In Busha cows AA genotype occurred in $44.44 \%, \mathrm{AB}$ in $55.56 \%$ animals and $\mathrm{BB}$ genotype was absent. These results for HF cows are in accordance with the findings of Lukač et al. (2013), who in HF cows found $23 \%$ with AA genotype, $58 \%$ with $\mathrm{AB}$ and $19 \%$ with $\mathrm{BB}$. Moreover, Dokso et al. (2014) found rather low frequencies of AA genotypes in HF (13.2\%), Simmental $(8.7 \%)$ and the Brown Cattle (15.9\%), high incidence of heterozygotes (57.9-67.0\%) and relatively high frequencies of $\mathrm{BB}$ homozygotes in comparison to our findings.

However, monitoring HF cows, Jersey cows and water buffalos, Ren et al. (2011) enabled to detect higher frequencies of $\mathrm{AA}$ genotypes $(55 \%)$ than $\mathrm{AB}$ $(28.7 \%)$ and BB (16.3\%) in HF cows, but in Jersey the $\mathrm{BB}$ genotype was more frequent $(77.2 \%)$ than $\mathrm{AB}(22.8 \%)$, whilst AA was not detected. In the autochthonous breed, water buffalo, the frequency of BB homozygotes (56.1\%) was significantly higher than that of AA homozygotes $(21.1 \%)$ and $\mathrm{AB}$ heterozygotes $(22.8 \%)$.

In the research conducted by Ivanković et al. (2011) on $130 \mathrm{HF}$ cattle and 30 Busha different genotype incidences were detected. In HF heterozygocity $(\mathrm{AB})$ was occurred most frequently $(59.35 \%)$, followed by BB homozygots (27.64 \%) and AA with merely $13.01 \%$. This roughly corresponds to our findings with the exception of BB homozygotic genotype, which was found to be less frequent in Serbian cattle. In Busha cows Ivanković et al. (2011) detected equal frequencies of $\mathrm{AA}$ and $\mathrm{AB}$ (35.29\% each), and $A A$ in $29.41 \%$. These data are in contrast with ours, due to the lack of BB homozygotes in our research, and the most abundant $\mathrm{AB}$ heterozygocity 
found in $50 \%$ animal. High numbers of heterozygocity in HF cows both in the current and previous research is supposed to result from the preference of bulls homozygotic to desirable polygenic traits.

The results of this research may prompt further investigations into the distribution of various genotypes for $\beta$ - $\mathrm{Lg}$ and $\kappa-\mathrm{CN}$ in dairy cows. If the correlation between milk yield/milk quality and certain genotypes will be high, the selection of autochthonous and high-producing cows in Serbia may be enabled.

\section{Acknowledgement}

This research was supported by the Ministry of Education, Science and Technological Development of the Republic of Serbia (Grant No. 46002).

\section{Istraživanje polimorfizma gena za $\kappa$-kazein $i$ beta-laktoglobulin u buše i holštajn- frizijske pasmine mliječnih krava u Srbiji}

\section{Sažetak}

Cilj istraživanja bio je utvrditi raspodjelu genotipova kapa-kazeina $(\kappa-\mathrm{CN})$ i beta-laktoglobulina $(\beta-\mathrm{Lg})$ $\mathrm{u}$ autohtonih (buša) i mliječnih (holstein, HF) pasmina goveda primjenom PCR-RFLP. Za amplifikaciju $\kappa-\mathrm{CN}$ i $\beta$-Lg fragmenata gena korištene su specifične oligonukleotidne početnice. Nakon digestije posebnim endonukleazama (Hinf I i Hae III) genotipovi su određeni za oba gena u 18 buša i 19 HF krava. Rezultati su pokazali da je $\kappa$-CN gen utvrđen genotipom AA u 31,58 \% HF krava, AB u 52,63 \% krava, dok je genotip $\mathrm{BB}$ utvrđen u samo 15,79 \% krava. Od krava pasmine buša $44,44 \%$ je imalo AA genotip i 55,56 $\%$ genotip $\mathrm{AB}$ za $\kappa$-CN. Što se tiče $\beta$ - $\mathrm{Lg}$ gena $\mathrm{u} \mathrm{HF}$ pasmine, AA genotip pronađen je u 26,31 \% krava, $\mathrm{AB} \mathrm{u} 63,16 \%$ i BB u 10,53 \% krava. U krava pasmine buša sljedeći genotipovi su utvrđeni za $\beta$-Lg gen: AA u 44,44 \% i AB u 55,56 \% krava, dok BB genotip nije utvrđen. Ovi rezultati pokazuju da je u krava pasmine buša veća prisutnost $\mathrm{A}$ alelne forme za oba ispitivana gena (za k-CN i $\beta$-laktoglobulin) nego kod HF krava.

Ključne riječi: $\kappa$-kazein, $\beta$-laktoglobulin, polimorfizam, PCR-RFLP, holstein, buša

\section{References}

1. Alipanah, M., Kalashnikova, L., Rodionov, G. (2005): Kappa-casein genotype frequencies in Russian breeds Black and Red Pied Cattle, Iranian Journal of Biotechnology 3 (3), 191-194.

2. Azevedo, A.L.S., Nascimento, C.S., Steinberg, R.S., Carvalho, M.R.S., Peixoto, M.G.C.D., Teotdoro, R.L., Verneque, R.S., Guimaraes, S.E.F., Machado, M.A. (2008): Genetic polymorphisms of the kappa-casein gene in Brazilian cattle, Genetics and Molecular Research 7 (3), 623-630. doi: 10.4238/vol7-3gmr428

3. Botstein, D., Raymond, L., White, M.S., Davis, R.W. (1980): Construction of agenetic linkage map in man using restriction fragment length polymorphisms, American Journal of Human Genetics 32 (3), 314-331.

4. Caroli, A.M., Chessa, S., Erhardt, G.J. (2009): Milk protein polymorphisms in cattle, effect on animal breeding and human nutrition, Journal of Dairy Science 92 (11), 5335-5352. doi: 10.3168/jds.2009-2461

5. Creamer, L., Parry, D., Malcolm, G. (1983): Secondary structure of $\beta$-lactoglobulin B, Archives of Biochemistry and Biophysics 227 (1), 98-105. doi: 10.1016/0003-9861(83)90351-X

6. Del Lama, S.N., Zago, M.A. (1996): Identification of kappa-casein and beta-lactoglobulin genotypes in Brazilian Bos indicus and Bubalus bubalis population, Brazilian Journal of Genetics 19 (1), 73-77.

7. Dokso, A., Ivanković, A., Brka, M., Zečević, E., Ivkić, Z. (2014): Utjecaj genetskih varijanti $\beta$-laktoglobulina, к-kazeina i asl-kazeina na količinu i kvalitetu mlijeka holstein, simentalske i smeđe pasmine goveda u Hrvatskoj, Mljekarstvo 64 (1), 49-56.

8. Golijow, C.D., Giovambattista, G., Poli, M., Dulout, F.N., Lojo, M.M. (1996): $\kappa$-casein gene frequencies support subdivision and historical origin of Argentine Creole cattle, Brazilian Journal of Genetics 19 (4), 583-586. doi: 10.1590/S0100-84551996000400008

9. Hallen, E., Wedholm, A., Andren, A., Lunden, A. (2008): Effect of beta-casein and beta-lactoglobulin genotypes on concentration of milk protein variants, Journal of Animal Breeding and Genetics 125 (2), 119-129. doi: 10.1111/j.1439-0388.2007.00706.x

10. Hill, J.P. (1997): The relationship between $\beta$-lactoglobulin phenotype and milk composition in New Zealand dairy cattle, Journal of Dairy Science 76 (1), 282-286.

11. Ivanković, A., Ramljak, J., Dokso, A., Kelava, N., Konjačić, M., Paprika, S. (2011): Genetski polimorfizam $\beta$-laktoglobulina i $\kappa$-kazeina pasmina goveda u Hrvatskoj, Mljekarstvo 61 (4), 301-308.

12. Kemens, P.A., Reginato L.C.A., Rosa, A.J.M., Parker, I.U., Razook, G.A., Figueiredo, E. (1999): א-casein, $\beta$-lactoglobulin and growth hormone allele frequencies and genetic distances in nelore, gyr, guzerá, car$\mathrm{acu}$, charolais, canchim and santagertrudis cattle, Genetics and Molecular Biology 22 (4), 539-541. doi: 10.1590/S1415-47571999000400012 
13. Lukač, D., Vidović, V., Nemeš, Ž., Stupar, M., VranješPopović, A. (2013): Genotypic frequencies of the $\beta$-lactoglobulin, $\mathrm{K}-\mathrm{k}$ asein and transferin in Serbian Hostein-Friesian dairy cattle, Mljekarstvo 63 (4), 203-210.

14. Lukač, D., Jovanovac, S., Nemes, Zs., Vidović, V., Popović-Vranješ, A., Raguž, N., Lopičić-Vasić, T. (2015): Association of polymorphism $\kappa$-casein gene with longevity and lifetime production of Holstein-Friesian cows in Vojvodina, Mljekarstvo 65 (4), 232-237.

15. Ma, X., Wang, X., Hu, G., Ma, G., Zhao, J., Peng, C., Chang, G. (2007): Analysis of genetic polymorphisms at $\kappa-\mathrm{CN}$ Exon 4 and Exon 5 in southern Chinese Holstein Cattle, China Dairy Cattle 2, 5-8.

16. Medrano, J.F., Aquilar-Cordova, E. (1990): Genotyping of bovine $\kappa$-casein loci following DNA sequence amplification, Biotechnology 8 (2), 144-146. doi: 10.1038/nbt0290-144

17. Mitra, A., Schlee, P., Krause, I., Blusch, J., Werner, T., Balakrishnan, C.R., Pirchner, F. (1998): Kappa-casein polymorphisms in Indian dairy cattle and Buffalo, a new genetic variant in Buffalo, Animal Biotechnology 9 (2), 81-87. doi: 10.1080/10495399809525896

18. Patel, J.B., Chauhan, K.M.S., Soni, K.J. (2007): Genotyping and allelic frequencies of $\mathrm{k}-\mathrm{CN}$ and $\beta-\mathrm{LG}$ in Indian river buffalo bulls, Buffalo Bulletin 26 (3), 63-66.

19. Scheepers, R.C., Marle-Koster, E., Visser, C. (2010): Genetic variation in the kappa-casein gene of South African goats, Small Ruminant Research 93 (1), 53-56. doi: 10.1016/j.smallrumres.2010.03.007
20. Sharma, V., Sharma, N., Jawed, B., Nautiyal, S.C., Sing, R.K. (2013): High Resolution melt curve analysis for the detection of Al, A2 $\beta$-Kazein variants in Indian cows, Journal of Microbiology and Biotechnology Research 3 (1), 144-148.

21. Stevanovic, J., Stanimirovic, Z., Dimitrijevic, V., Maletic, M. (2010): Evaluation of 11 microsatellite loci for their use in paternity testing in the Yugoslav Pied cattle (YU Simmental cattle), Czech Journal of Animal Science 55 (6), 221-226.

22. Stanimirovic, Z., Stevanovic, J. (2012): Primena molekularno-genetičkih analiza u veterinarskoj medicini. Zbornik predavanja sa XXXIII Seminara za inovacije znanja veterinara, Feb 24, Beograd, Srbija, pp. 17-33,

23. Stanimirović, Z., Simeunović, P., Vučićević, M., Davitkov, D., Stanišić, Lj., Maletić, M., Gajić, B., Glavinić, U., Stevanović, J. (2015): Primena molekularno-genetičkih analiza $\mathrm{u}$ forenzici i dijagnostici kod domaćih životinja i divljači, Zbornik predavanja 36. Seminara za inovacije znanja veterinara, Feb 20, Beograd, pp. 137-146.

24. Ju, Z., Li, Q., Wang, H., Li, J., An, O., Yang, W., Zhong, J., Wang, F. (2008): Genetic polymorphism of $\kappa$-casein gene exon 4 and its correlation with milk production traits in Chinese Holsteins, Yi Chuan 30 (10), 1312-1318. doi: 10.3724/SP.J.1005.2008.01312 